\title{
Dekarbonizacja Europy a hydraty metanu
}

\section{Decarbonization of Europe and methane hydrates}

\author{
Piotr Such \\ Instytut Nafty i Gazu - Państwowy Instytut Badawczy
}

STRESZCZENIE: Unia Europejska przyjęła ambitny plan dekarbonizacji gospodarki. Do roku 2050 państwa UE powinny zmniejszyć emisję $\mathrm{CO}_{2}$ o $90 \%$ w porównaniu z rokiem 1990 i osiągnąć tzw. neutralność $\mathrm{CO}_{2}$. W tym programie szereg celów jest oczywistych i nie podlega dyskusji. Są natomiast pewne uwarunkowania, którymi do tej pory nikt się specjalnie nie przejmuje, a które mogą postawić cały program pod znakiem zapytania. Niniejszy artykuł koncentruje się na problemie podmorskich złóż hydratów metanu. Metanu w hydratach jest więcej niż wszystkich pozostałych paliw kopalnych razem wziętych. Ich złoża zalegają głównie na dnie oceanu światowego. Aktualnie współistnieją trzy teorie dotyczące hydratów:

- $\quad$ złoża hydratów to ogromne źródło energii i nadchodzi nowa złota epoka eksploatacji metanu;

- $\quad$ złoża hydratów to bomba zegarowa - globalne ocieplenie spowoduje masową dysocjację złóż hydratów, co zwiększy w stopniu katastrofalnym skalę ocieplenia;

- $\quad$ ocean nagrzewa się tak wolno, że mamy jeszcze kilkaset lat do ewentualnej dysocjacji złóż hydratów.

W zasadzie można by się zgodzić z trzecim podejściem, gdyby nie Golfstrom. Ten prąd oceaniczny niesie do Arktyki ogromne ilości ciepła, które dokładają się do ogólnego ocieplenia klimatu. W związku z tym możliwe są trzy efekty dla tych akwenów, przez które płynie Golfstrom. Są to: dysocjacja złóż hydratów, powodująca masową ucieczkę metanu do atmosfery; ewentualne osunięcia osadów na skłonach szelfu związane z utratą stabilności złóż hydratów; zmiana warunków termobarycznych złóż hydratów spowodowana cofaniem się lądolodu. Dodatkowym efektem będzie uwolnienie metanu zalegającego pod złożami hydratów. Istnieją już modele pozwalające na symulowanie zachowania się złóż hydratów. Podstawowym problemem jest brak odpowiednich danych. Stworzenie bazy danych zawierającej:

- mapę zasięgu występowania złóż hydratów znajdujących się w zasięgu Golfstromu oraz ich głębokości zalegania (być może konieczne będzie również opracowanie modelu transportu ciepła przez warstwy skał oddzielające złoża hydratów od wody);

- $\quad$ pomiary temperatur powierzchniowych i przydennych wód Golfstromu (tu badania powinny trwać kilka lat, aby można było wychwycić trendy zmian),

pozwoli na realne prześledzenie możliwych scenariuszy dotyczących metanu ze złóż hydratów.

Słowa kluczowe: dekarbonizacja, hydraty metanu, globalne ocieplenie, Golfstrom.

ABSTRACT: The European Union accepted the ambitious project of decarbonization of economy. The main goal is a 90 percent reduction of $\mathrm{CO}_{2}$ emissions in comparison with 1990 emissions, which will result in the so-called climatic neutrality. In this project, several goals are obvious and not subject to discussion. But there are several conditions, previously not discussed, which could bring this program into question. This paper concentrates on the problem of methane hydrates. Methane hydrate reservoirs mainly occupied the bottom of the oceans and the volume of methane in these reservoirs is greater than the volume of hydrocarbons in all other reservoirs. Currently, three different theories about hydrates coexist:

- the methane hydrates is a huge energy source and a new golden age is coming;

- the methane hydrates are a time bomb - global warming causes dissociation of these reservoirs and a global warming catastrophe;

- the ocean is warming so slowly that we have several hundreds of years until eventual dissociation of methane hydrate reservoirs. Essentially, the third approach could be applied if it was not for Gulf Stream. This ocean current brings a great amount of heat to the Arctic region. It is an additional factor of global warming. Therefore, three effects are possible for the ocean areas through which Gulf Stream flows. There is methane hydrates reservoirs dissociation causing methane migration into the atmosphere, sediment landslides on shelf slopes and the associated potential tsunami, and change of thermobaric conditions connected with vanished ice sheet. The free methane cumulated under methane hydrate deposits will also migrate into the atmosphere. Appropriate models for simulation of all these possibilities do exist, however we do not have sufficient data. Thus, creation of a reliable data base is the first goal. Maps of extents of hydrate reservoirs, depth of reservoirs and results of several years of examinations of surface and bottom temperatures must be gathered in this database. This will allow us to investigate all possible scenarios.

Key words: decarbonization, methane hydrates, global warming, the Gulf Stream.

Autor do korespondencji: P. Such, e-mail: piotr.such@inig.pl

Artykuł nadesłano do Redakcji: 01.06.2020 r. Zatwierdzono do druku: 24.09.2020 r. 


\section{Wstęp}

W publikacji przedstawiono krótki przegląd aktualnych trendów w polityce energetycznej Unii Europejskiej, a konkretnie planu dekarbonizacji gospodarek państw Unii Europejskiej. Następnie skoncentrowano się na problematyce związanej $\mathrm{z}$ występowaniem hydratów metanu w przyrodzie. Tworzą one ogromne złoża tego surowca na dnach mórz i oceanów, pod lądolodem i pod wieczną zmarzliną. Dla jednych jest to potencjalnie związane z nową erą obfitości energetycznej, dla innych z zagrożeniem. W artykule omówiono punkty krytyczne dotyczące złóż hydratów ulokowanych wokół Europy.

\section{Krótki przegląd obecnych trendów energetycznych w UE}

Program dekarbonizacji Europy (Komisja Europejska, 2019) zakłada zmniejszenie emisji $\mathrm{CO}_{2}$ do $90 \%$ i osiągnięcie neutralności klimatycznej do roku 2050.

Program będzie obejmował:

- $\quad$ koniec finansowania inwestycji związanych z ropą i gazem + harmonogram całkowitego odchodzenia od węgla;

- wykorzystanie OZE;

- wprowadzenie wodoru jako źródła energii;

- elektryfikację i wodoryzację samochodów;

- zmiany w rolnictwie;

- zalesianie.

Jest to plan ambitny, natomiast jego wykonalność może stwarzać problemy. Do silnych stron tego programu można zaliczyć determinację Komisji Europejskiej związaną z jego wdrażaniem. Natomiast jeśli chodzi o jego merytoryczną zawartość, to część postulowanych zmian jest jednoznacznie pozytywna - dotyczy to wykorzystania OZE oraz technologii wodorowych. Tutaj efekty uboczne są praktycznie zerowe, natomiast technologie te w sposób istotny ograniczają wykorzystanie paliw kopalnych. Ich wprowadzenie jako zasadniczych źródeł energii będzie wymagało stworzenia efektywnego systemu magazynowania energii elektrycznej i wodoru. Brak metod efektywnego magazynowania energii sprawia, że te technologie są dzisiaj stosowane jako uzupełniające. Absolutnie pozytywnym elementem programu jest również zalesianie.

Co do innych punktów:

- Samochody elektryczne. Produkcja akumulatorów wymaga dużych ilości energii. Wydobywanie i separacja pierwiastków ziem rzadkich powoduje ogromne szkody w środowisku. W sumie ślad węglowodorowy samochodu elektrycznego odpowiada około 40 tys. km przebiegu samochodu benzynowego, i to tylko pod warunkiem, że prąd służący do ładowania akumulatorów jest pozyskiwany ekologicznie (bezemisyjnie). Tak jest w przypadku Francji, gdzie 75\% energii elektrycznej pochodzi z elektrowni jądrowych, natomiast w Polsce byłoby to przejście z samochodów napędzanych benzyną lub olejem silnikowym na samochody napędzane węglem.

- Zmiany w rolnictwie. Obecnie rolnictwo w Europie odpowiada za 34\% emisji gazów cieplarnianych (głównie krowy, produkujące i wydzielające metan). Aby zrealizować założenia programu dekarbonizacji, należałoby zlikwidować połowę stad bydła. Biorąc pod uwagę dotychczasowe doświadczenia Komisji Europejskiej z rolnikami, może to być bardzo trudne.

- W programie nie ma wzmianki o energetyce jądrowej - jedynym tak naprawdę ekologicznym źródle energii dostępnym całą dobę i niezależnym od przyrody. Głośne protesty ludzi niemających pojęcia o energetyce jądrowej spowodowały odłożenie tej dziedziny energetyki (w Europie) do lamusa. Przy czym biorąc pod uwagę liczbę ofiar związanych z innymi rodzajami energii (z przyczyn takich jak zapylenie, wypadki przy produkcji stali i akumulatorów, a nawet przy budowie, konserwacji i eksploatacji farm wiatrowych), jest to najbezpieczniejsza technologia pozyskiwania energii (włączając w to bilans katastrof elektrowni w Czarnobylu i Fukushimie - notabene powodem pierwszej z nich były niedopuszczalne i nieodpowiedzialne eksperymenty „,naukowe”, a drugiej tsunami, a więc nie były to awarie elektrowni)

I to tyle o Europie. Europa to jednak nie cały świat. Jesteśmy, jeśli chodzi o produkcję energii, coraz mniej znaczącą jego częścią - a inne kraje nie mają zamiaru ograniczyć spalania paliw kopalnych, tak więc temperatura na Ziemi będzie się podnosić. Oznacza to kolejny problem ogólnoświatowy, w którym Europa chcąc nie chcąc będzie uczestniczyć. Jest to problem hydratów metanu.

\section{Hydraty metanu}

Generalnie o hydratach jako strukturach krystalicznych wiemy dużo i są to dane ścisłe. Natomiast gdy przechodzimy do występowania hydratów metanu w przyrodzie, nasza wiedza jest - mówiąc delikatnie - niekompletna, co pozwala na pewną dwoistość w pisaniu o nich. Z jednej strony znaleźć można prace wskazujące, że w hydratach metanu jest zawarte więcej energii niż we wszystkich pozostałych paliwach kopalnych (co jest prawdą) (Makogon, 1997; Szpunar, 2005; Zaporożec i Szostak, 2014) i czeka nas nowa świetlana era energetyczna, z drugiej strony - prace ostrzegające, że to tykająca bomba zegarowa (co też jest prawdą) (Jabłońska, 2010; Rabajczyk, 2011; Pharmpus i Hornbach, 2012). 


\section{Definicja i niektóre właściwości hydratów metanu}

Hydraty metanu to struktury krystaliczne lodu i metanu. Obrazowo rzecz ujmując, lód tworzy klatki dla cząstek metanu (stąd też inna nazwa: klatraty). Z punktu widzenia energetyczno-ekologicznego właściwości tych kryształów są następujące: hydraty metanu zachowują stabilność w określonych warunkach termobarycznych. W warunkach normalnych z jednego litra hydratów metanu uwalnia się 168 litrów metanu (Sloan i Koh, 2008; Zaporożec i Szostak, 2014), tak więc jest to potencjalna bomba. Generalnie hydraty rozkładają się przy wzroście temperatury lub spadku ciśnienia poniżej stanu stabilności (Henry et al., 1999).

\section{Rozmieszczenie i oszacowanie ilości hydratów metanu}

Rysunek 1 przedstawia obecny stan rozpoznania zalegania złóż hydratów na świecie, jak również ich wielkości, to znaczy więcej w nim domniemań niż faktów. Rabajczyk (2009) podaje, że do tej pory przebadano około 3\% dna oceanów i praktycznie bardzo niewiele wiadomo o specyficznym ekosystemie stworzonym przez hydraty. Szacunki ilości metanu zalegającego w hydratach też różnią się od siebie w zależności od źródła o przeszło trzy rzędy wielkości. W swojej monumentalnej pracy Zaporożec i Szostak (2014) podają aktualne szacunki ilości hydratów na świecie od $3,1 \times 10^{15} \mathrm{~m}^{3}$ do $7,6 \times 10^{18} \mathrm{~m}^{3}$. Mimo ogromnej różnicy w oszacowaniach nawet ich minimalna wielkość jest imponująca.

Złoża hydratów zalegają pod dnem oceanów, pod wieczną zmarzliną oraz pod lądolodem. Pod nimi zalega natomiast dodatkowo jeszcze bliżej nieokreślona, lecz również imponująca

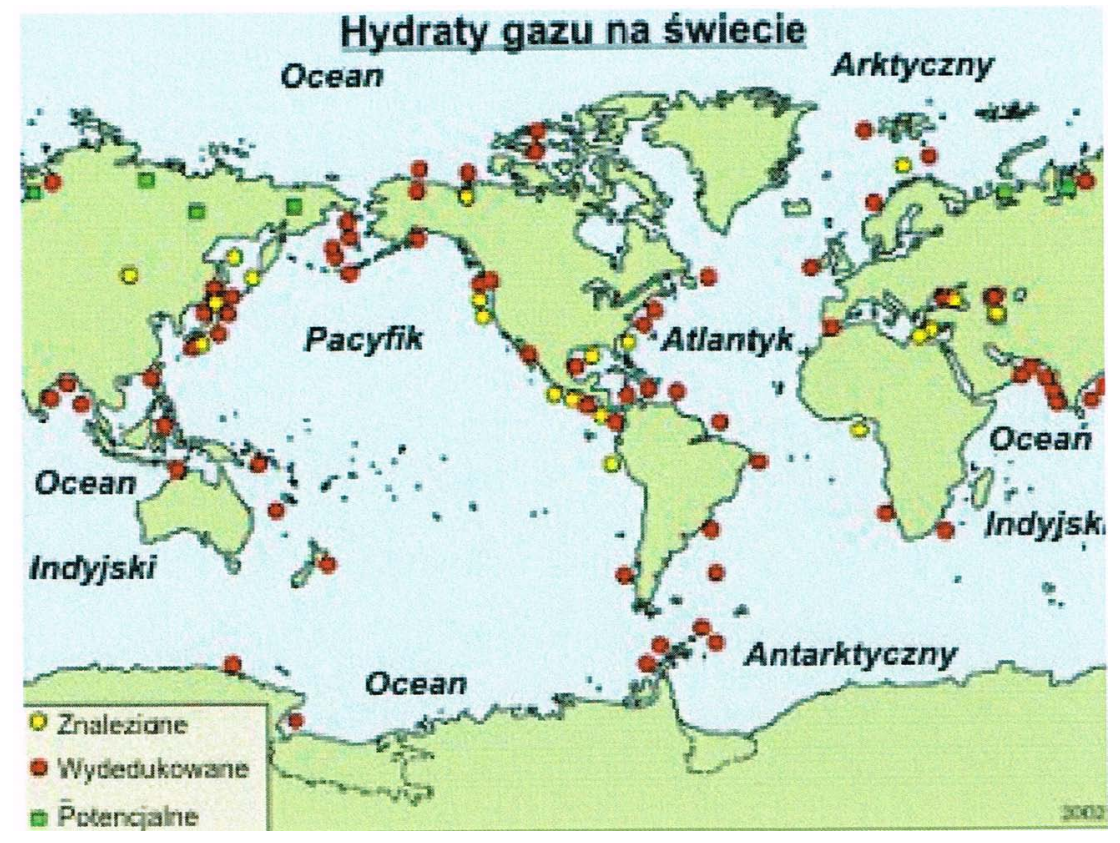

Rys. 1. Hydraty gazu (metanu) na świecie (znalezione, wydedukowane i potencjalne) (źródło: USGS za Wikipedią)

Fig. 1. Methane hydrates in the world (found, deduced and potential) (Wikipedia: after USGS) ilość wolnego metanu (Wallmann et al., 2018). Metanu w hydratach, nawet przy oszacowaniu minimalnym, jest więcej niż wszystkich węglowodorów z innych źródeł razem wziętych. Obecnie koegzystują ze sobą trzy teorie dotyczące hydratów:

1. Według pierwszej z nich hydraty to prawie niewyczerpane źródło energii i niedługo rozpocznie się złota epoka ich energetycznego wykorzystania. Duże sukcesy w próbach eksploatacji metanu z hydratów na morzu (i cały szereg patentów) mają Japończycy (Zagórski, 2013). Twierdzą oni, że w ciągu kilku lat rozpoczną opłacalną ekonomicznie eksploatację w przemysłowej skali. Aktualnie badania i próbną eksploatację na lądzie i szelfie prowadzą USA, Kanada, Rosja (i też mają swoje patenty). Zainteresowane tym źródłem energii są również Chiny, Indie, Korea Płd. (Makogon i Holditch, 2005; Zaporożec i Szostak, 2014). W sumie do tej pory wykryto na świecie 230 złóż hydratów.

2. Zgodnie $\mathrm{z}$ drugą teorią, ponieważ hydraty metanu rozkładają się pod wpływem temperatury, a mamy do czynienia z globalnym ociepleniem, to niedługo doprowadzimy do masowej ucieczki metanu $\mathrm{z}$ hydratów oraz metanu zalegającego pod złożami hydratów do atmosfery. Ich masowe uwalnianie się do atmosfery było prawdopodobną przyczyną największych zmian klimatycznych w historii Ziemi (są one bowiem 30 razy bardziej wydajnym gazem cieplarnianym niż $\mathrm{CO}_{2}$ ). Katastrofa nadchodzi szybkimi krokami i pistolet metanowy jest już w nas wymierzony (Haq, 1998).

3. Trzecia teoria twierdzi, że co prawda globalne ocieplenie następuje, tym niemniej ocean światowy będzie się nagrzewał o wiele wolniej i mamy zapewne setki, a maksymalnie nawet tysiąc lat, do niebezpieczeństwa masowego uwalniania się metanu. Tę hipotezę można generalnie przyjąć za najbardziej prawdopodobną.

Aktualną wiedzę o złożach hydratów na świecie można zawrzeć w jednym zdaniu: metanu w hydratach jest bardzo dużo, a złoża hydratów rozmieszczone są w różnych miejscach na świecie (głównie w oceanach).

\section{Wracając do Europy}

W wodach okalających Europę również znajdują się złoża hydratów metanu. Dotyczy to Oceanu Arktycznego (ze szczególnym uwzględnieniem Mórz Barentsa i Północnego), wybranych rejonów Atlantyku, Morza Czarnego. Złoża hydratów oraz wolny metan występuja również pod lądolodem Arktyki (Grenlandia, Spitsbergen). 


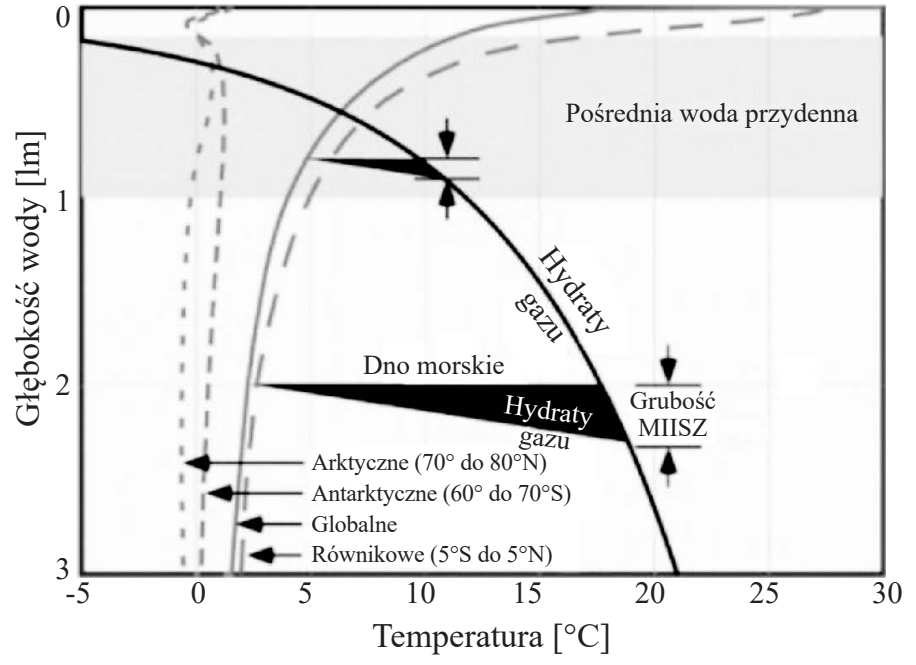

Rys. 2. Obszary stabilności istnienia złóż hydratów (Jabłońska, 2010)

Fig. 2. Ranges of gas hydrate deposits (Jabłońska, 2010)

W zasadzie można by przyjąć teorię trzecią (oceany ogrzewają się tak wolno, że złoża hydratów jeszcze przez kilkaset lat będą stabilne), gdyby nie istnienie Golfstromu. Ten prąd oceaniczny niesie do Arktyki ogromne ilości ciepła, które dokładają się do ogólnego ocieplenia klimatu. W rezultacie ta część Ziemi ogrzewa się najszybciej. To jeszcze nie jest najgorsze. Krytyczne punkty są następujące:

- Ciepłe wody Golfstromu, które zaczęły wlewać się do Morza Barentsa. To zmieniło na tyle równowagę termobaryczną złóż hydratów (rys. 2), że ilość metanu uwalniająca się z tych złóż na terenach, do których dotarly wody Golfstromu, jest coraz większa z roku na rok. Tutaj zmiany są bardzo szybkie w odróżnieniu np. od tych obszarów Morza Północnego, w których wody mieszały się z Golfstromem od dawna. To jest nowa i ogromna zmiana w termobarycznej sytuacji złóż hydratów Morza Barentsa (Vadakkepuliyambatta et al., 2017; Caesar et al., 2018).

- Drugim szybkim procesem zmieniającym równowagę termobaryczną złóż hydratów jest topnienie lądolodu Arktyki. Dotyczy to obszarów lądu stałego, jak Grenlandia, Spitsbergen, i terenów przybrzeżnych, gdzie lądolód wspiera się na dnie, zaś jego topnienie w sposób zdecydowany zmieni warunki termobaryczne potencjalnych złóż hydratów (rys. 2) i może doprowadzić do masowego uwalniania się metanu (Zaporożec i Szostak, 2014; Cremiere et al., 2016; Serov et al., 2016).

- Trzecim efektem będzie uwolnienie się wolnego biogenicznego gazu znajdującego się pod złożami hydratów, pod wieczną zmarzliną bądź pod lądolodem. Szacuje się, że objętość tego gazu jest równa $1 / 3$ do $2 / 3$ objętości gazu zawartego w hydratach (Wallmann et al., 2018).

- Rozkład złóż hydratów znajdujących się na skłonach szelfu może doprowadzić do zaburzenia równowagi mechanicznej tych skłonów i do powstania osuwisk, które mogą spowodować naprawdę katastrofalne tsunami. Takie procesy już miały miejsce (kilka tysięcy lat temu) i są dość dobrze przebadane, zarówno jeśli chodzi o mechanizm powstawania, jak i o skalę potencjalnych zniszczeń (Higgins i Schrag, 2006; Rabajczyk, 2011; Mienert, 2012).

Problemem samym w sobie jest Golfstrom, jako że tu również istnieją dwa punkty widzenia:

- Golfstrom jest coraz słabszy i zaniknie, a w konsekwencji ustanie transport ciepła do Arktyki, czego efektem będzie nadejście nowej epoki lodowej. Ta koncepcja jest bardzo nagłośniona, jednak nie znajduje ona wystarczającego potwierdzenia w faktach.

- Golfstrom jest obecnie słabszy o $15-20 \%$ i jest to proces naturalny, związany ze zmianami klimatycznymi. Zmienia się północnoatlantycka cyrkulacja prądów morskich i między Ameryką Północną a Grenlandią temperatura tej części oceanu się obniża. Zmiana cyrkulacji powoduje dodatkowo przesunięcie Golfstromu w stronę Norwegii. Tym niemniej Morze Północne (a więc m.in. szelf Norwegii), Morza Karskie i Barentsa są cieplejsze o 3 stopnie, a to już powoduje przejście części złóż hydratów w stan metatrwały i utratę metanu. Tu rzeczywiście powstało szereg poważnych i udokumentowanych prac naukowych (Pharmpus i Hornbach, 2012; Caesar et al., 2018).

\section{Dyskusja i wnioski}

Wiarygodne publikacje na tematy związane $\mathrm{z}$ hydratami metanu to zupełny margines w porównaniu z propagandą, jaką znaleźć można w Internecie. Prześledzenie rzetelnych publikacji pozwala na ogólny wniosek: istnieją modele ewentualnego uwalniania się metanu do atmosfery, natomiast nie mamy odpowiednich danych. Vadakkepuliyambatta et al. (2017) modelują potencjalną ucieczkę metanu ze złóż hydratów na Morzu Barentsa do 2060 roku i prezentują rozbieżności wyników od 1,8 Gt do 7 Gt metanu, który się uwolni w zależności od przyjętych założeń. Należy podkreślić, że jest to ten sam model, ale $\mathrm{z}$ rożnymi, równo prawdopodobnymi danymi wejściowymi. Powstały poważne prace wiążące uwalniający się metan w Arktyce ze zmianami spowodowanymi przez cofający się lądolód po epoce lodowcowej (Hornbach et al., 2004; Shakhova et al., 2013; Serov et al., 2016). W Arktyce zatem następują również zmiany, w stosunkowo wolnym tempie.

Innymi słowy, nie jesteśmy w stanie zweryfikować, który z poniższych scenariuszy się sprawdzi:

1) zmiany następują, ale na tyle małe, że metan będzie się uwalniał stopniowo przez kilkaset lat i jego większość 
zostanie zagospodarowana naturalnie przez stworzony przez niego ekosystem (Rabajczyk, 2009; Cremiere et al., 2016);

2) może dojść do szybkiego rozkładu złóż hydratów na skłonie szelfu, co doprowadzi do katastrofalnego tsunami;

3) może dojść do masowego i szybkiego uwalniania się metanu ze złóż hydratów i swobodnego metanu zalegającego pod nimi, co w znacznym stopniu zwiększy skalę globalnego ocieplenia;

4) że temperatura Arktyki się obniża i hydraty zostaną pod lodem (koncepcje nowej epoki lodowej).

Na obecnym etapie rozpoznano zachowanie się złóż hydratów w zmiennych warunkach termobarycznych, mamy przygotowane odpowiednie modele termicznej ewolucji basenu, brakuje natomiast:

- mapy obszaru występowania złóż hydratów w zasięgu Golfstromu pokazującej głębokości ich zalegania - być może konieczny będzie model transportu ciepła przez warstwy skał oddzielające złoża hydratów od wody;

- pomiarów temperatur powierzchniowych i przydennych wód Golfstromu - tutaj badania powinny trwać kilka lat, aby można było wychwycić trendy zmian.

Uzbrojeni w tę wiedzę oraz odpowiednie modele będziemy mogli z dużą pewnością stwierdzić, że albo możemy spokojnie dekarbonizować Europę, albo uzasadnionym ekologicznie działaniem będzie szybkie rozpoczęcie eksploatacji określonych złóż hydratów i budowa Arctic Stream.

\section{Literatura}

Caesar L., Rahmstrof S., Robinson H., Feulner G., Saba V., 2018. Observed fingerprint of a weaking Atlantic Ocean overturning circulation. Nature, 556: 191-196. DOI: 10.1038/s41586-018-00-6-5.

Cremiere A., Lepand A., Chand S., Sahy D., Condon J., Noble S.R., Thorsens T., Sauer S., Brunstad H., 2016. Timescales of methane seepage on the Norwegian Sheet. Nature Communications, 7(11509). DOI: 10.1038/ncomms 11509.

Haq B.U., 1998. Gas hydrates: greenhouse nightmare? Energy panacea or pipe dream? GSA Today, 11: 1-6.

Henry P., Thomas M., Clennel M.B., 1999. Formation of natural gas hydrates in marine sediments: 2 . Thermodynamics calculations of stability conditions in porous sediments. Journal of Geophysical Research, 104: 23005-23022.

Higgins J.A., Schrag D.P., 2006. Beyond methane: Towards a theory for the Paleocene-Eocene Thermal Maximum. Earth and Planetary Science Letters, 245: 523-537.

Hornbach M.J., Saffer D.M., Holbrook W.S., 2004. Critically pressured free-gas reservoirs below gas-hydrate provinces. Nature, 427(6970): 142-144.

Jabłońska M.M., 2010. Hydraty metanu źródłem zanieczyszczenia atmosfery i środowiska. Nafta-Gaz, 3: 203-210.
Komisja Europejska, 2019. Europejski Zielony Ład. Komunikat Komisji do Parlamentu Europejskiego, Rady Europejskiej, Rady, Komitetu Ekonomiczno-Społecznego i Komitetu Regionów. Bruksela, 11.12.2019 r. COM(2019) 640 final.

Makogon Y.F., 1997. Hydrates of hydrocarbons. Tulsa: Penn Well Books: 200. ISBN 0-87814-718-7.

Makogon Y.F., Holditch S.A., 2005. Russian field illustrates gas hydrate production. Oil and Gas Journal, 103: 41-47.

Mienert J., 2012. Signs of instability. Nature, 490: 491-492. DOI: 10.1038/490491a.

Pharmpus B.J., Hornbach M.J., 2012. Recent changes to the Gulf Stream causing widespread gas hydrate destabilization. Nature, 490(7421): 527-530. DOI: 10.1038/nature11528.

Rabajczyk A., 2009. Stabilność klatratów metanu a środowisko. Rocznik Świętokrzyski, Ser. B - Nauki Przyrodnicze, 30: 39-55.

Rabajczyk A., 2011. Zagrożenia dla środowiska wynikające z eksploatacji klatratów metanu - studium oceny oddziaływania na środowisko. Górnictwo i Geoinżynieria, 35(4/1): 321-329.

Serov P., Vadakkepuliyambatta S., Mienert J., Patton H., Portnov A., Silyakova A., Panieri G., Carroll M., Carroll J., Andreassen K., Hubbard A., 2016. Postglacial response of Arctic Ocean gas hydrates to climatic amelioration. PNAS, 114(24): 6215-6220. DOI: $10.1073 /$ pnas. 1619288114.

Shakhova N., Semiletov I., Leifer I., Sergienko V., Salyuk A., Kosmach D., Chernykh D., Stubbs Ch., Nicolsky D., Tumskoy V., Gustafsson O., 2013. Ebullition and storm-induced methane release from the East Siberian Arctic Shelf. Nature Geoscience, 7(1): 275-286.

Sloan E.D., Koh C.A., 2008. Clathrate hydrates of natural gases. Taylor \& Francis, CRC Press. ISBN 9780849390784.

Szpunar T., 2005. Hydraty - zasoby gazy ziemnego. Nafta-Gaz, 11: 492-494.

Vadakkepuliyambatta S., Chand S., Bunz S., 2017. The history and future trends of ocean warming-induced gas hydrate dissociation in the SW Barents Sea. Geophysical Research Letters, 44(2): 835-844. DOI: 10.1002/2016GL071841.

Wallmann K., Riedel M., Hong W.L., Patton H., Hubbard A., Pape T., Hsu C.W., Schmidt C., Johnson J.E., Torres M.E., Andreasses K., Berndt C., Bohrmann G., 2018. Gas hydrate dissociation off Svalbard induced by isostatic rebound rather than global warming. Nature Communications, 9(1):83. DOI: 10038/ s41467-017-02550-9.

Zagórski J., 2013. Gazohydraty - nowy rodzaj paliw kopalnych. Przeglad Geologiczny, 61: 452-459.

Zaporożec E.P., Szostak N.A., 2014. Gidraty. Izdatielnyj Dom -Jug, Krasnodar. ISBN 978-5-91718-355-8.

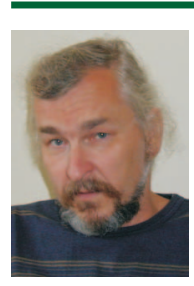

Dr hab. Piotr SUCH, prof. INiG - PIB

Zastępca Dyrektora ds. Poszukiwań Złóż

Węglowodorów

Instytut Nafty i Gazu - Państwowy Instytut Badawczy

ul. Lubicz 25 A

31-503 Kraków

E-mail: piotr.such@inig.pl 